\title{
PENGEMBANGAN MODUL SUHU DAN KALOR DENGAN PENDEKATAN SAINTIFIK UNTUK MELATIHKAN LITERASI SAINS PESERTA DIDIK DI SMA
}

\author{
Heni Fadilah*, Dedy Hamdani, Andik Purwanto \\ Program Studi S1 Pendidikan Fisika FKIP Universitas Bengkulu \\ Jl. WR. Supratman, Kandang Limun, Bengkulu \\ e-mail*: henifadilah2016@gmail.com
}

\begin{tabular}{c|c|c}
\hline Diterima 15 Juli 2020 & Disetujui 29 Desember 2021 & Dipublikasikan 14 Januari 2022 \\
\hline & https://doi.org/10.33369/jkf.4.3.185-192 & \\
\hline
\end{tabular}

\begin{abstract}
ABSTRAK
Penelitian ini bertujuan untuk: 1) mengembangkan modul suhu dan kalor dengan pendekatan saintifik untuk melatihkan literasi sains peserta didik di SMA; 2) mengetahui karakteristik modul suhu dan kalor yang dikembangkan dengan pendekatan saintifik untuk melatihkan literasi sains peserta didik di SMA; dan 3) mengetahui kelayakan penggunaan modul suhu dan kalor dengan pendekatan saintifik untuk melatihkan literasi sains peserta didik di SMA. Penelitian ini dilakukan dengan desain 4-D yang memiliki empat tahap yaitu tahap Define (Pendefinisian), Design (Perancangan), Develop (Pengembangan, dan Desseminate (Penyebaran), namun pada penelitian ini hanya dilaksanakan sampai tahap Develop. Instrumen penilaian yang digunakan dalam penelitian ini adalah lembar validasi ahli yang berisi aspek materi, aspek karakteristik modul, aspek bahasa dan aspek media. Adapun karakteristik modul yang dikembangkan, terdapat langkah pendekatan saintifik pada konsep dan lembar kegiatan mandiri. Terdapat soal teori, soal hitungan dan soal literasi sains untuk melatihkan kemampuan literasi sains peserta didik. Berdasarkan hasil uji validasi produk oleh ahli diperoleh skor rata-rata dengan persentase 75\% untuk aspek materi, 84,37\% untuk aspek karakteristik modul, 83,33\% untuk aspek bahasa, dan $79,16 \%$ untuk aspek media, sehingga total skor rata-rata adalah $80,46 \%$ yang termasuk ke dalam kategori sangat baik. Dengan demikian modul suhu dan kalor dengan pendekatan saintifik untuk melatihkan literasi sains peserta didik di SMA menjadi produk jadi yang layak digunakan untuk uji lapangan.
\end{abstract}

Kata kunci: Suhu dan kalor, pendekatan saintifik, literasi sains

\begin{abstract}
This research aimed to: 1) develop a temperature and heat module with a scientific approach to train students' scientific literacy in high school; 2) find out the characteristics of the temperature and heat module that was developed with a scientific approach to practicing scientific literacy of students in high school; and 3) determine the feasibility of using a temperature and heat module with a scientific approach to practice scientific literacy of students in high school. This research was carried out with 4-D design that had four stages, namely the Define, Design, Develop and Desseminate stages, but in this research it was only carried out until the Develop stage. This is an expert validation sheet that contains material aspects, aspects of module characteristics, language aspects and media aspects, while the module characteristics are developed, there is a scientific approach to the concepts and independent activity sheets, there are theoretical questions, calculation questions and scientific literacy questions to practice the ability of students. Based on the results of the product validation test by the expert obtained an average score of $75 \%$ for the material aspect, $84.37 \%$ for the module characteristic aspect, $83.33 \%$ for the language aspect, and $79.16 \%$ for the media aspect, so that the total average score is $80.46 \%$ which is included in the excellent category, thus the temperature and heat module with scientific approach to practice scientific literacy of students in high school into a finished product that is suitable for field testing.
\end{abstract}

Keywords: Temperature and heat, scientific approach, scientific literacy

\section{PENDAHULUAN}

Pendidikan bukan sekedar pengajaran dalam arti mentransfer ilmu tetapi pendidikan merupakan proses pembebasan peserta didik dari ketidaktahuan, ketidakmampuan, ketidakberdayaan, dan ketidakbenaran (1). Tujuan pendidikan adalah untuk menghasilkan sumber 
daya manusia yang berkualitas yang mampu bersaing dengan tenaga kerja lainnya sesuai dengan kompetensi yang dimilikinya dalam menghadapi persaingan global. Perlu di bangun proses pembelajaran yang berkualitas yang memberi kesempatan kepada peserta didik untuk terlibat aktif dalam membangun konsep dari materi yang dipelajarinya. Guru harus meninggalkan paradigma pembelajaran yang monoton dan menggantinya dengan paradigma pembelajaran konstruktivistik, dimana pembelajaran tidak lagi berpusat pada guru melainkan peserta didik (2).

Keberhasilan dalam pembelajaran salah satunya dapat dipengaruhi oleh penggunaan sumber belajar yang digunakan. Interaksi yang terjadi dalam pembelajaran dikelas adalah antara peserta didik, guru dan bahan ajar. Guru bertugas untuk menyediakan bahan ajar yang dapat digunakan oleh peserta didik untuk memperoleh pelajaran yang akan dipelajari (3)

Dalam pembelajaran terjadi proses belajar mengajar dimana biasanya guru menjelaskan materi pelajaran kepada peserta didik, ataupun peserta didik mencari sendiri materi pembelajaran menggunakan sumber belajar yang ada. Banyak sekali sumber belajar yang dapat digunakan oleh peserta didik, salah satunya adalah modul. Modul merupakan suatu jenis bahan ajar yang dikemas secara sistematis dan lengkap untuk membantu peserta didik belajar secara mandiri dengan ataupun tanpa guru untuk mencapai tujuan pembelajaran. Sebuah penelitian menyatakan bahwa modul efektif untuk digunakan dalam pembelajaran karena modul dapat digunakan dengan waktu yang dapat ditentukan sendiri (4).

Metode pembelajaran dengan menggunakan modul adalah metode pembelajaran yang dilakukan dengan menyiapkan satu paket belajar yang berisi konsep tunggal mengenai bahan pembelajaran (5). Modul berisi materi pelajaran yang akan dipelajari oleh peserta didik. Salah satu materi pelajaran yang wajib dipelajari oleh peserta didik SMA adalah pelajaran fisika.

Fisika pada hakikatnya merupakan ilmu pengetahuan yang mempelajari tentang gejala-gejala alam yang terjadi dari serangkaian proses yang disebut proses ilmiah dan akan menghasilkan produk ilmiah yang tersusun atas tiga komponen yaitu konsep, prinsip dan teori yang berlaku secara universal (6)

Guru harus pandai memilih pendekatan yang tepat agar peserta didik dapat memahami materi pelajaran yang diajarkan (7). Salah satu pendekatan yang dianjurkan oleh kurikulum 2013 adalah pendekatan saintifik. Pembelajaran dengan pendekatan saintifik merupakan proses pembelajaran yang dirancang untuk membantu peserta didik agar secara aktif dapat mengkonstruk konsep, hukum atau prinsip melalui tahapan mengamati, merumuskan masalah, mengolah data, menarik kesimpulan dan mengkomunikasikan konsep yang ditemukan. Pendekatan saintifik dimaksudkan untuk memberikan pemahaman kepada peserta didik untuk dapat memahami materi pelajaran dengan pendekatan ilmiah bahwa informasi dapat diperoleh dari mana saja bukan hanya dari guru (8).

Fenomena alam yang terjadi dalam kehidupan sehari-hari bisa digunakan sebagai contoh dan permasalahan nyata di dalam modul. Fenomena alam yang terjadi dalam kehidupan sehari- hari dapat diaplikasikan ke dalam modul melalui pendekatan saintifik untuk melatihkan literasi sains peserta didik. Literasi sains adalah kemampuan yang dimiliki seseorang untuk memahami sains, serta menerapkan pengetahuan sains untuk memecahkan masalah sehingga memiliki sikap dan kepekaan yang tinggi terhadap diri dan lingkungannya dalam mengambil keputusan berdasarkan konsep-konsep sains (9). Hasil PISA tahun 2015 menyatakan bahwa Indonesia masih menempati salah satu negara dengan peringkat literasi sains yang rendah. Peserta didik Indonesia masih berada dibawah rata-rata nilai sains negara OECD, sehingga kemampuan literasi sains peserta didik harus dilatih agar mengalami peningkatan.

Hasil analisis kebutuhan dan observasi yang dilakukan, berdasarkan keterangan guru, kemampuan yang dimiliki peserta didik masih kurang, setelah diamati buku ajar yang digunakan oleh peserta didik dalam proses pembelajaran fisika adalah lembar kegiatan siswa (LKS) yang hanya memuat sedikit ringkasan materi. Sedangkan peserta didik yang menggunakan buku lain hanya sedikit. Buku-buku yang digunakan sepenuhnya belum menunjang peserta didik dalam belajar sehingga peserta didik kurang termotivasi (8). 
Keberhasilan dalam pembelajaran salah satunya dipengaruhi oleh penggunaan sumber belajar yang digunakan dalam proses pembelajaran. Interaksi yang terjadi dalam pembelajaran di kelas adalah antara peserta didik, guru dan bahan ajar. Guru bertugas untuk menyediakan bahan ajar untuk digunakan oleh peserta didik untuk memperoleh materi pelajaran untuk belajar mandiri. Dengan demikian perlu adanya bahan ajar seperti modul yang dapat menunjang kegiatan pembelajaran disekolah sehingga keberhasilan dalam pembelajaran dapat tercapai (3).

Keunggulan penggunaan modul dalam proses pembelajaran adalah modul dapat mengatasi keterbatasan waktu, ruang dan daya indera peserta didik, meningkatkan motivasi belajar peserta didik dan memungkinkan peserta didik dapat belajar secara mandiri sesuai dengan kemampuan dan minatnya sehingga modul dapat menggantikan peran guru dalam proses pembelajaran dan memperoleh informasi serta pengetahuan (Setiyadi, Ismail, \& Gani, 2017).

Pembelajaran fisika menggunakan pendekatan saintifik memungkinkan untuk dapat melatih kemampuan literasi sains peserta didik. Hal ini diperoleh dari penelitian terdahulu dalam pembelajaran mekanika, hasil menunjukkan bahwa pendekatan saintifik dapat meningkatkan kemampuan literasi sains pada kategori sedang dengan nilai peningkatan sebesar 0,61. Informasi lebih lanjut disarankan untuk dilakukan pendekatan dengan materi lainnya agar dapat membantu menlatihkan kemampuan literasi sains pada banyak materi sehingga kegiatan pembelajaran akan lebih meningkat (10).

Berdasarkan latar belakang yang telah di jelaskan diatas, maka perlu dilakukan penelitian tentang "Pengembangan Modul Suhu dan Kalor dengan Pendekatan Saintifik untuk Melatihkan Literasi Sains Peserta Didik di SMA". Adapun tujuan dari penelitian ini adalah 1) mengembangkan modul suhu dan kalor dengan pendekatan saintifik untuk melatihkan literasi sains peserta didik di SMA; 2) mengetahui karakteristik modul suhu dan kalor yang dikembangkan dengan pendekatan saintifik untuk melatihkan literasi sains peserta didik di SMA; dan 3) mengetahui kelayakan penggunaan modul suhu dan kalor dengan pendekatan saintifik untuk melatihkan literasi sains peserta didik di SMA.

\section{METODE PENELITIAN}

Metode penelitian yang digunakan pada penelitian ini adalah metode Research and Development (R\&D). Metode penelitian dan pengembangan adalah metode penelitian yang digunakan untuk menghasilkan produk tertentu dan menguji keefektifan produk tersebut (11). Desain penelitian yang digunakan pada penelitian ini adalah model 4D yang terdiri dari 4 tahap yaitu define (pendefinisian), design (perancangan), develop (pengembagan), dan desseminate (penyebaran). Tahapan penelitian 4D dapat dilihat pada gambar 1 berikut.

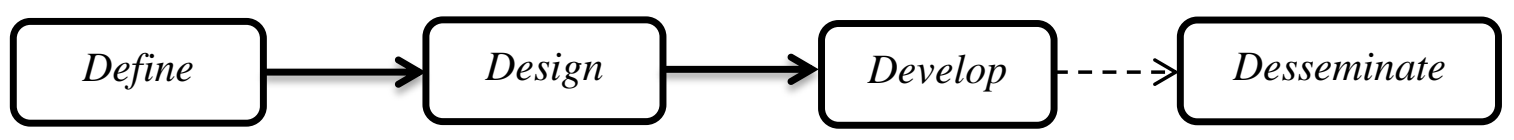

Gambar 1. Tahapan Penelitian dengan Desain 4D

Pada gambar 1 ditunjukkan tahap-tahap pengembangan modul dengan model 4D. Namun, pada penelitian ini hanya sampai tahap develop tidak sampai tahap desseminate (penyebaran), dikarenakan keterbatasan waktu dan biaya serta pada penelitian ini hanya sampai uji keterbacaan sehingga tidak perlu penyebaran. Adapun penjelasan dari tahap-tahap tersebut adalah sebagai berikut.

\subsection{Define (Pendefinisian)}

Tahap difine bertujuan untuk mendefinisikan masalah atau kekurangan-kekurangan yang ada pada pembelajaran fisika serta kebutuhan akan bahan ajar tambahan sehingga dibutuhkannya pengembangan modul dengan cara analisis kebutuhan yang diperoleh dari data artikel dari jurnaljurnal terdahulu.

\subsection{Design (Perancangan)}

Tahap design dilakukan perancangan instrumen penelitian berdasarkan silabus dan analisis kebutuhan yang telah dilakukan pada tahap define yaitu modul sebagai produk yang dikembangkan 
dan angket validasi ahli yang digunakan untuk mem-validasi produk yang dikembangkan dan divalidasi oleh dua validator. Adapun angket validasi ahli berisi empat aspek yang dinilai, yaitu aspek materi, aspek karakteristik modul, aspek bahasa dan aspek media (tampilan modul). Angket berisi 28 pernyataan yang disusun dengan menggunakan skala likert 4 tingkat yang berisi pernyataan positif dan pernyataan negatif. Skala likert empat tingkat dapat dilihat pada tabel 1 berikut.

Tabel 1 Skala Likert Empat Tingkat

\begin{tabular}{cc}
\hline Jawaban & Skor \\
\hline Sangat setuju & 4 \\
Setuju & 3 \\
Tidak setuju & 2 \\
Sangat tidak setuju & 1 \\
\hline
\end{tabular}

Berdasarkan tabel 1 skala likert yang digunakan pada penelitian ini adalah skala empat tingkat. Penggunaan skala likert empat tingkat pada penelitian ini bertujuan untuk menghilangkan kelemahan yang terdapat pada skala likert lima tingkat. Pada skala likert lima tingkat terdapat pilihan ragu-ragu atau pilihan ditengah antara setuju ataupun tidak setuju, sehingga jika disediakan pilihan jawaban tersebut akan menghilangkan banyak data dan informasi yang memungkinkan dapat diperoleh dari validator.

\subsection{Develop (Pengembangan)}

Tahap develop adalah tahap untuk menghasilkan produk yang dikembangkan. Tahap ini dilakukan validasi produk yang telah dikembangkan dan revisi produk berdasarkan komentar dan saran dari validator.

Teknik analisis data pada penelitian ini menggunakan data kualitatif dan kuantitatif. Data kualitatif berisi tanggapan dan saran dari validator terhadap modul yang dikembangkan. Sedangkan data kuantitatif diperoleh dari penilaian angket validasi ahli. Data kualitatif yang berupa komentar dan saran dari masing-masing validator digunakan sebagai pertimbangan dalam melakukan revisi modul pembelajaran yang dikembangkan (12). Sedangkan data kuantitatif harus dihitung dari angket validasi dari tim ahli. Rumus presentase yang digunakan untuk menganalisis data kuantitatif adalah sebagai berikut.

Rumus untuk mengolah data per item

$$
p=\frac{x}{x_{i}} \times 100 \%
$$

Rumus untuk mengolah data secara keseluruhan item.

$$
p=\frac{\sum x}{\sum x_{i}} \times 100 \%
$$

Dengan $p$ adalah persentase hasil penilaian, $x=$ skor yang diberikan responden pada satu item $x_{i}$ $=$ skor tertinggi pada satu item $\sum x=$ jumlah skor keseluruhan jawaban responden dan $\sum x_{i}=$ jumlah skor tertinggi $\mathrm{x}$ jumlah item $\mathrm{x}$ jumlah responden. Kriteria penilaian oleh ahli dapat dilihat pada tabel 2 berikut.

Tabel 2 Persentase Skor Validasi Produk

\begin{tabular}{cc}
\hline Persentase $(\%)$ & Kelayakan \\
\hline $\mathbf{0}-\mathbf{4 9 , 9 9}$ & Sangat Tidak Baik \\
$\mathbf{5 0 , 0 0}-\mathbf{5 9 , 9 9}$ & Kurang Baik \\
$\mathbf{6 0 , 0 0}-\mathbf{7 9 , 9 9}$ & Baik \\
$\mathbf{8 0}-\mathbf{1 0 0}$ & Sangat Baik \\
\hline
\end{tabular}

Berdasarkan tabel 2, modul dapat dikatakan layak apabila mendapat perolehan skor dengan persentase antara $60 \%-100 \%$. Sedangkan jika skor yang diperoleh tidak mencapai persentase $60 \%$, maka modul tidak layak untuk digunakan. 


\section{HASIL DAN PEMBAHASAN}

\subsection{Hasil}

\subsubsection{Define}

Tahap ini dilakukan analisis kebutuhan untuk mengetahui kekurangan-kekurangan ataupun masalah yang terjadi pada pembelajaran fisika. Seharusnya analisis kebutuhan pada penelitian ini dilakukan di beberapa sekolah menengah atas di Bengkulu. Namun dikarenakan sedang dalam masa pandemi covid-19, analisis kebutuhan langsung ke lapangan tidak dapat dilakukan karena semua sekolah di Bengkulu diliburkan. Analisis kebutuhan pada penelitian ini diperoleh dari data jurnal penelitian terdahulu yang berkaitan dengan pengembangan modul dengan pendekatan saintifik.

Hasil analisis kebutuhan dari data artikel jurnal-jurnal terdahulu didapat bahwa berdasarkan keterangan guru, kemampuan yang dimiliki peserta didik masih kurang, setelah diamati buku ajar yang digunakan oleh peserta didik dalam proses pembelajaran adalah LKS yang hanya memuat sedikit ringkasan materi. Sedangkan peserta didik yang menggunakan buku lain hanya sedikit. Buku-buku yang digunakan sepenuhnya belum menunjang peserta didik dalam belajar sehingga peserta didik kurang termotivasi (8).

Bahan ajar yang ada belum memenuhi kebutuhan pembelajaran fisika yang sesuai dengan kurikulum 2013 sebanyak 73,33\%. Analisis awal pada modul yang telah ada ternyata modul belum mengadopsi langkah-langkah saintifik secara utuh dan terbatasnya tampilan atau layout. Oleh sebab itu, dikembangkan modul untuk digunakan sebagai media pembelajaran pendukung untuk meningkatkan kualitas proses belajar peserta didik (14)

Materi yang dibahas pada modul ini adalah materi suhu dan kalor, materi ini dipilih karena berdasarkan hasil ujian nasional Tahun Pelajaran 2013/2014 menunjukkan bahwa daya serap peserta didik pada materi suhu dan kalor masih rendah yaitu pada tingkat kabupaten sebesar $72,61 \%$, tingkat provinsi sebesar $72,22 \%$ dan tingkat nasional sebesar $68,76 \%$. Daya serap peserta didik MAN Selong pada materi ini lebih rendah dari pada materi lain, sehingga materi suhu dan kalor masih dianggap materi yang sulit bagi peserta didik (15).

Hasil PISA tahun 2015 menyatakan bahwa Indonesia masih mejadi salah satu negara dengan peringkat literasi sains yang rendah. Peserta didik Indonesia masih berada dibawah rata-rata nilai sains negara OECD. Kemampuan literasi sains peserta didik indonesia baru mencapai skor 403, sedangkan negara OECD adalah 493. Hal ini berarti kemampuan literasi sains peserta didik Indonesia harus dilatih agar dapat mengalami peningkatan (16).

\subsubsection{Design}

Tahap design dilakukanlah perancangan instrumen penelitian yaitu angket validasi produk dan perancangan modul. Angket validasi produk oleh ahli berisi empat aspek penilaian, yaitu aspek materi, aspek karakteristik modul, aspek bahaa dan aspek media (tampilan modul). Modul dirancang berdasarkan silabus dimana materi suhu dan kalor memiliki empat materi pokok yang harus dipelajari oleh peserta didik sekolah menengah atas. Keempat materi tersebut adalah suhu dan pemuaian, hubungan kalor dengan perubahan wujud zat, Azas Black dan perpindahan kalor. Selain silabus, modul juga dirancang berdasarkan analisis kebutuhan yang telah didapat pada tahap define sebelumnya dengan menggunakan pendekatan saintifik yang terdiri dari lima tahap pembelajaran, yaitu tahap mengamati, tahap menanya, tahap mencoba, tahap mengolah data dan tahap mengkomunikasikan hasil pengamatan atau pemecahan masalah yang telah dilakukan oleh peserta didik. Berdasarkan silabus dan hasil analisis kebutuhan dari tahap define, didapatlah desain produk modul yang dapat dilihat pada Gambar 2 berikut. 


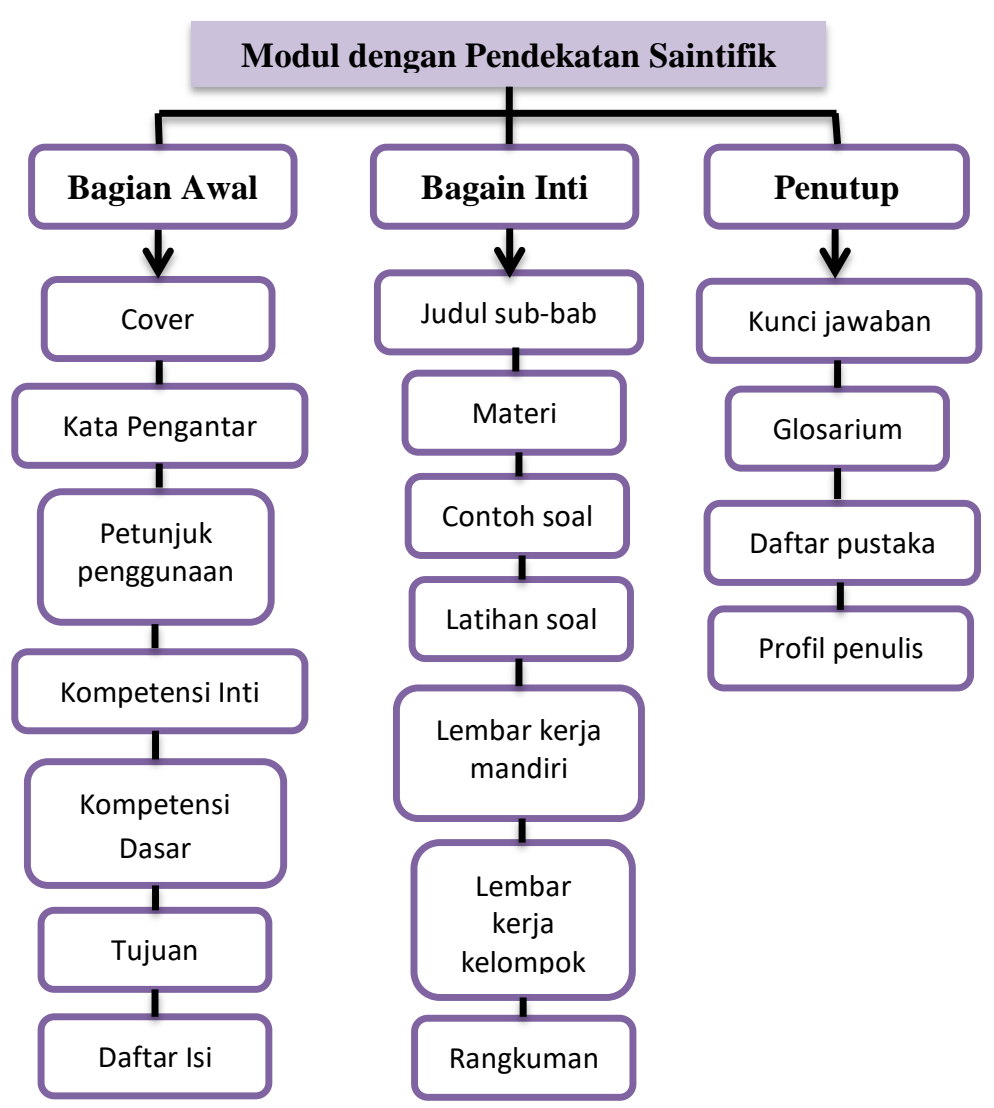

Gambar 2. Rancangan Produk

Berdasarkan Gambar 2, dapat dilihat bahwa modul memiliki tiga bagian penting, yaitu bagian awal yang berisi cover, kata pengantar, pentunjuk penggunaan modul, kompetensi inti, kompetensi dasar, tujuan pembelajaran dan daftar isi. Bagian inti yang berisi judul sub-bab, materi, contoh soal, latihan soal, lembar kerja mandiri, lembar kerja kelompok dan rangkuman. Bagian penutup yang berisi kunci jawaban, glosarium, daftar pustaka dan profil penulis.

\subsubsection{Develop}

Hasil rancangan produk pada tahap design divalidasi oleh dua validator untuk mengetahui kelayakan modul suhu dan kalor dengan pendekatan saintifik untuk melatihkan literasi sains peserta didik di SMA.. Hasil validasi aspek materi, karakteristik modul, bahasa dan media dapat dilihat pada tabel 2 berikut.

Tabel 2 Hasil Akhir Validasi Kelayakan Modul oleh Ahli

\begin{tabular}{ccc}
\hline Aspek & Persentase (\%) & Kategori \\
\hline Materi & 75 & Baik \\
Karakteristik modul & 84,37 & Sangat baik \\
Bahasa & 83,33 & Sangat baik \\
Media & 79,16 & Baik \\
Jumlah & 80,46 & Sangat baik \\
\hline
\end{tabular}

Berdasarkan tabel 2, dapat dilihat hasil akhir dari uji validasi produk oleh kedua validator mendapatkan penilaian total rata-rata seluruh aspek sebesar 80,46\% dan masuk ke dalam kategori sangat baik. Produk telah direvisi berdasarkan komentar dan saran dari kedua validator yaitu penambahkan tujuan pembelajaran, penambahkan penjelasan mengenai titik didih dan titik beku, penambahkan keterangan pada persamaan yang ada, penambahkan penjelasan pada persamaan, latihan soal dijadikan soal essay, simbol kalor jenis seharusnya c kecil bukan $\mathrm{C}$ besar, penambahan penjelasan mengenai gambar skema perubahan wujud zat, grafik perubahan es menjadi uap air dijelaskan, gambar pada lembar kegiatan mandiri Azas Black tidak jelas, penjelasan terjadinya angin darat dan angin laut, energi yang diserap oleh benda hitam, rumus suhu benda $T$ memancarkan energi kesekitarannya yang bersuhu $T_{0}$, pertanyaan literasi sains, kunci jawaban 
diuraikan, penjelasan bagaimana jika kalor yang merambat dari benda yang bersuhu rendah ke benda yang bersuhu tinggi, contoh koefisien muat beberapa zat, ditambahkan kegiatan percobaan, sertakan sumber jika gambar yang diambil bukan dari hasil foto sendiri, background dirubah polos dan pada cover gunakan foto yang diambil sendiri.

\subsection{Pembahasan}

\subsubsection{Mengembangkan Modul}

Modul dibuat berdasarkan analisis kebutuhan yang didapat. Modul sebagai alternatif dalam keterbatasan bahan ajar yang ada. Materi suhu dan kalor dipilih karena masih rendahnya hasil ujian nasional peserta didik. kemampuan literasi sains perlu dilatihkan untuk meningkatkan kemampuan literasi sains peserta didik. Modul berisi empat kegiatan belajar berdasarkan materi pokok pada silabus. Kegiatan belajar 1 berisi materi suhu dan pemuaian yang memuat materi, contoh soal, latihan soal dan lembar percobaan. Kegiatan belajar 2 berisi materi hubungan kalor dengan suhu benda dan wujudnya yang memuat materi, contoh soal, latihan soal dan lembar percobaan. Kegiatan belajar 3 berisi materi Azas Black yang memuat materi, contoh soal, latihan soal dan lembar percobaan. Kegiatan belajar 4 berisi materi perpindahan kalor secara konduksi, konveksi dan radiasi yang memuat materi, contoh soal, latihan soal dan lembar percobaan. Modul selain berisi empat kegiatan belajar, juga memuat rangkuman materi, kunci jawaban agar peserta didik dapat mencocokkan jawaban yang didapat dengan jawaban yang benar. Pada bagian akhir modul terdapat daftar pustaka yang berisi sumber-sumber data mengenai materi suhu dan kalor, glosarium yang berisi kata-kata penting beserta artinya dan profil penulis yang berisi informasi penulis.

\subsubsection{Karakteristik Modul}

Karakteristik modul suhu dan kalor dengan pendekatan saintifik untuk melatihkan literasi sains berisi tahapan-tahapan pendekatan saintifik yang meliputi tahap mengamati (observing), tahap menanya (questioning), tahap mencoba (experimenting), tahap mengolah data (associating) dan tahap mengkomunikasikan (communicating) hasil pengamatan atau pemecahan masalah dari suatu masalah. Lima tahapan-tahapan pendekatan saintifik tersebut terdapat pada konsep dan lembar kerja mandiri sebagai tahap-tahap yang harus dilakukan peserta didik untuk menemukan jawaban dari fenomena yang disediakan. Adapun, kemampuan yang ingin dilatihkan adalah kemampuan literasi sains yang meliputi kemampuan memahami pertanyaan, menyelesaikan masalah, dan menarik kesimpulan. Modul menyediakan latihan soal yang memuat soal teori, soal hitungan dan soal literasi sains (C4) yang dapat digunakan untuk melatihkan literasi sains peserta didik.

\subsubsection{Kelayakan Modul}

Kelayakan modul dapat dilihat dari hasil penilaian angket validasi produk oleh ahli. Berdasarkan hasil penilaian angket validasi oleh ahli, diperoleh persentase nilai rata-rata pada aspek materi sebesar 75\% dengan kategori baik, aspek karakteristik modul sebesar 84, \% dengan kategori sangat baik, aspek bahasa sebesar 83,33\% dengan kategori sangat baik dan aspek media (tampilan modul) $79,16 \%$ dengan kategori baik. Jumlah presentase total ke empat aspek sebesar 80,46\% yang termasuk ke dalam kategori sangat baik. Hasil akhir yang diperoleh ini relevan dengan penelitian yang dilakukan oleh Sukiminiandari, Budi dan Supriyati (14) dengan penelitian yang berjudul pengembangan modul pembelajaran fisika dengan pendekatan saintifik. Berdasarkan hasil penelitiannya dapat disimpulkan bahwa modul yang dikembangkan layak untuk digunakan sebagai bahan ajar fisika dengan hasil validasi oleh ahli materi sebesar 87,33\% dan hasil validasi oleh ahlli media sebesar $87,71 \%$.

Hasil penelitian ini juga relevan dengan penelitian yang dilakukan oleh Darmawan, Aminah dan Sukarmin (15) dengan penelitian yang berjudul pengembangan modul pembelajaran fisika berbasis saintifik untuk meningkatkan keterampilan berpikir kritis siswa SMA/MA. Berdasarkan hasil penelitiannya modul yang dikembangkan layak untuk digunakan dengan hasil perhitungan oleh ahli materi, ahli media, ahli bahasa, guru dan teman sejawat yang memperlihatkan nilai ratarata 85 penilaian lebih besar dari cut off 84 .

Komentar dan saran yang diberikan oleh kedua validator telah dijadikan pedoman untuk melakukan perbaikan atau revisi produk, hasil revisi produk dari validator telah di konsultasikan oleh kedua pembimbing skripsi. Sehingga, modul suhu dan kalor dengan pendekatan saintifik untuk 
melatihkan literasi sains peserta didik di SMA telah menjadi produk jadi yang layak digunakan untuk uji coba lapangan.

\section{SIMPULAN DAN SARAN}

Berdasarkan penelitian yang telah dilakukan: 1) Pengembangan modul didasari oleh silabus dan analisis kebutuhan yang didapat dari jurnal terdahulu; 2) Karakteristik modul yang dikembangkan adalah konsep dan lembar kerja mandiri menggunakan tahap pendekatan saintifik yaitu: tahap mengamati, menanya, mencoba, mengolah data dan mengkomunikasikan. Disediakan latihan soal yang memuat soal teori, soal hitungan dan soal literasi sains untuk melatihkan literasi sains peserta didik yang meliputi kemampuan memahami pertanyaan, menyelesaikan masalah, dan menarik kesimpulan; dan 3) Modul suhu dan kalor dengan pendekatan saintifik untuk melatihkan literasi sains peserta didik di SMA sudah layak digunakan untuk diuji coba kelapangan.

Penelitian selanjutnya diharapkan: 1) Tes literasi sains peserta didik perlu dilakukan sebelum dan setelah menggunakan modul, agar dapat terlihat perbedaan kemampuan literasi sains peserta didik sebelum dan sesudah menggunakan modul; dan 2) Penelitian ini hanya sampai tahap develop, untuk penelitian selanjutnya disarankan untuk melanjutkan sampai tahap desseminate.

\section{DAFTAR PUSTAKA}

1. Fananie. Pedoman Pendidikan Modern. Solo: Tiga Serangkai Pustaka Mandiri; 2011.

2. Erawanto S. Pengembangan Modul Pembelajaran Berbasis Masalah untuk Membantu Meningkatkan Berpikir Kreatif Mahasiswa. 2016;2(November):427-36.

3. Sirate SFS, Ramadhana R. Pengembangan modul pembelajaran berbasis keterampilan literasi. : $316-35$.

4. Utami TN, Jatmiko A, Suherman S. Pengembangan Modul Matematika dengan Pendekatan Science, Technology, Engineering, And Mathematics (STEM) pada Materi Segiempat. Desimal J Mat. 2018;1(2):165.

5. Sunantri, Suyatna, Rosidin. Pengembangan Modul Pembelajaran Menggunakan Learning Content Development System Materi Usaha dan Energi. (1):107-17.

6. Trianto. Model Pembelajaran Terpadu. Jakarta: PT Bumi Aksara; 2012.

7. Kalinda PKD, Maharta N, Ertikanto C. Pengembangan Modul Pembelajaran Fisika Berbasis Inkuiri Terbimbing Pada Materi Suhu dan Perubahannya. :123-32.

8. Kriyanto B, Suparmi, Sarwanto. Pengembangan Modul Fisika dengan Pendekatan Saintifik Materi Listrik Statis untuk Peserta Didik Kelas XII SMA / MA. 2019;9:10-8.

9. Asyhari A, Hartati R. Profil Peningkatan Kemampuan Literasi Sains Siswa Melalui Pembelajaran Saintifik. 2015;04(2):179-91.

10. Setiawan AR. Peningkatan Literasi Saintifik Melalui Pembelajaran Biologi Menggunakan Pendekatan Saintifik. J Biol Educ. 2019;2(1):1.

11. Sugiyono. Metode Penelitian Pendidikan. Bandung: Alfabeta; 2010.

12. Aji SD, Hudha MN. Pengembangan Modul Pembelajaran Fisika Berbasis Problem Based Learning untuk Meningkatkan Kemampuan Pemecahan Masalah Fisika. Sci Educ J. 2017;1(1):36-51.

13. Latifah S, Setiawati E, Abdul B. Pengembangan Lembar Kerja Peserta Didik (LKPD) Berorientasi Nilai-Nilai Agama Islam Melalui Pendekatan Inkuiri Terbimbing Pada Materi Suhu dan Kalor. 2016;05(April):43-51.

14. Sukiminiandari YP, Budi AS, Supriyati Y. Pengembangan Modul Fisika dengan Pendekatan Saintifik. Pros Semin Nas Fis. 2015;IV:161-4.

15. Darmawan I, Aminah NS, Sukarmin. Pengembangan Modul Pembelajaran Fisika Berbasis Saintifik untuk Siswa SMA/MA.

16. Narut YF, Supardi K. Literasi Sains Peserta Didik dalam Pembelajaran IPA di Indonesia. 2013;61-9. 